\title{
How do for-Profit Colleges and Universities Maintain Enrolment Rates to continue their Financial Health
}

\author{
Luis Miguel Dos Santos \\ Woosong Language Institute, Woosong University, Daejeon, South Korea. \\ Email:Lluismigueldossantos@yahoo.com
}

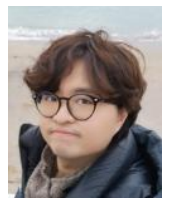

\begin{abstract}
For-profit, post-secondary institutions significantly increased in numbers within the last two decades. In the United States, many for-profit colleges and universities offer distance-learningbased and self-paced-based academic and vocational programs from certificate to doctoral degree level to non-traditional, returning, evening and adult students who cannot enrol at one of the oncampus, day-time programs for traditionally-aged and full-time students. A large number of forprofit colleges and universities employ different strategies to maintain effective numbers of student enrolment and collect enough budget for financial health. This literature paper explains the overview of for-profit colleges and universities in the United States including donation and income sources, enrolment management, employment management and customer-oriented service with the question of how for-profit colleges and universities can survive in the current, rapidly changing environment containing many different competitors. The literature review also provides a brief section about how nursing programs at the for-profit colleges and universities continue their operation in the current financial and educational environment.
\end{abstract}

Keywords: College administration, College financial management, Enrolment management, Faculty management, For-profit colleges and universities, Distance learning.

Citation | Luis Miguel Dos Santos (2020). How do for-Profit Colleges and Universities Maintain Enrolment Rates to continue their Financial Health. Journal of Education and e-Learning Research, 7(1): 69-75.

History:

Received: 17 December 2019

Revised: 27 January 2020

Accepted: 2 March 2020

Published: 7 April 2020

Licensed: This work is licensed under a Creative Commons

Attribution 3.0 License (cc) E

Publisher: Asian Online Journal Publishing Group
Funding: This study received the Woosong University Academic Research Funding 2020.

Competing Interests: The author declares that there are no conflicts of interests regarding the publication of this paper.

Transparency: The author confirms that the manuscript is an honest, accurate, and transparent account of the study was reported; that no vital features of the study have been omitted; and that any discrepancies from the study as planned have been explained.

Ethical: This study follows all ethical practices during writing.

\section{Contents}

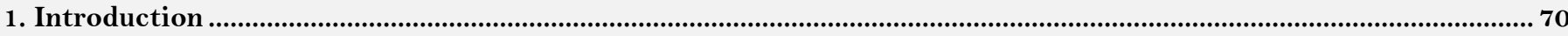

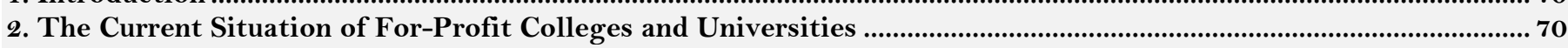

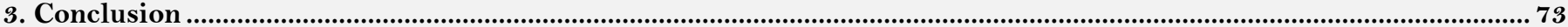

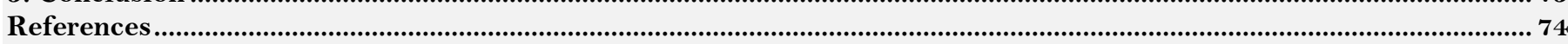




\section{Contribution of this paper to the literature}

This paper contributes to the field of for-profit and online education, distance learning programs, and college and university administration.

\section{Introduction}

Schools, higher education institutions, colleges and universities are where students build up self-discipline, establish independence and creativity and create attachments to groups (Brint, 2006). Higher education has been advocated as an appropriate way to promote people from a lower-class status to a better social position (Bowen, 1982; Brint \& Karabel, 1989; Rubin, 2012). Traditionally, higher education enrolment is often reserved for upper class people in society. General and local residents without any networks or connections could not usually participate in any college or university education, due to social bias and social class differences. Particularly female learners, minorities, and people with disabilities, a college or university education was one of the most different directions and goals for them to achieve due to discrimination and social bias against minority groups. As a result, females and minority populations did not usually pursue any college or university qualifications, particularly the baby boomer generation. Therefore, a large number of for-profit colleges and universities were established for the purpose of providing college and university education to minority groups and busy working professionals.

For-profit institutions refer to profit-making schools which provide vocational certificates, academic certificates, associate degrees, bachelor's degrees, masters degrees and doctoral degrees in different concentrations. These profit-making, post-secondary institutions are quickly growing and providing new opportunities for students to experience vocational and post-secondary education. The University of Phoenix-Online Campus and Kaplan University have been ranked with the first and second-highest total enrolment for degree-granting colleges and universities in the United States. The enrolment number of the University of Phoenix was 380,232 and that of Kaplan University was 71,011. Both the universities are considered as distance-based and for-profit institutions.

\subsection{Purpose of This Study}

The United States is one of the countries and regions where a large number of for-profit colleges and universities have been established. In order to gain a brief understanding of the performance and operational management of these for-profit colleges and universities, this literature review has established three purposes for this study, as below.

First, the purpose of this review is to examine the different types of activities of for-profit higher education institutions designed to maintain financial health. Second, this review also notes the issues of how for-profit higher education institutions attract students, and how do these institutions survive in a rapidly changing market, while simultaneously building a strong revenue. Third, the literature review is divided into several parts to explain the various solutions and perspectives of strategic planning of for-profit colleges and universities, such as financial plans, curriculum changes and practitioner-oriented program establishment. The following literature reviews attempt to demonstrate the financial and enrolment management of for-profit colleges and universities in the United States.

\section{The Current Situation of For-Profit Colleges and Universities}

\subsection{Overview of For-Profit Colleges and Universities in the United States}

During the last two decades, the arena of higher education has significantly changed. A large number of forprofit, post-secondary educational institutions have been founded in the United States to respond to different types of students (Honick, 1995). More than 800 for-profit institutions are registered to teach knowledge to students. These institutions have received state, regional and national accreditation from the Department of Education. Many of these institutions have the ability to grant vocational certificates up to doctoral level degrees (Deming, Goldin, \& Katz, 2012). The enrolment rate of for-profit institutions does not exceed 10 per cent of the total enrolment rate of post-secondary education, but the growth in for-profit enrolment is considerable. Moreover, the increase in the number of for-profit institutions has already made traditional colleges and universities revisit their marketing strategies for attracting students (Cellini, 2010). As mentioned above, one of the best-known for-profit institutions is the University of Phoenix-Online Campus (Breneman, 2006) which served as the largest institution in the United States with more than 380,000 students. There are many kinds of research on for-profit institutions regarding social impact, traditional school interactions, student satisfaction, distance learning and technology (Banerjee, 2011; Cellini, 2010). But not much single research material contains all the considerable elements concerning the impact and strategic management of for-profit colleges.

A study Johnstone and Marcucci (2010) suggested several recommendations and solutions for for-profit colleges and universities to reduce the overall daily operational expenses. However, reducing the number of instructors is not enough to support reducing the overall operational expenses. The efforts to reduce college expenses can be divided into different categories as shown below, including the reasons why for-profit colleges and universities prefer to exercise these concepts. First, a short cycle per term refers to a normal semester term containing 16-weeks of instruction, which means four months of teaching activities (Killingsworth, McCurry, \& Hastie, 2006). However, many colleges and universities have already changed their academic terms from semesterbased into quarter-based or term-based to reduce the coursework duration (Breneman, 2006). Generally, many universities in the United States require 120-semester credits to graduate and 210 to 220 quarter credits for graduation. To meet the enrolment requirement, by changing from four quarters per year to the equivalent of three semesters per year, the program can take advantage of this to increase the size of classroom enrolment numbers or increase the number of sections offered to the total enrolment (Chung, 2012).

In many for-profit colleges and universities, many schools applied the first strategy which was to increase the enrolment number of each section. As for the financial perspective, first, a higher enrolment rate is equivalent to 
higher tuition income from the students, but the salary of the professors does not increase. In other words, when the school is getting more students into the classroom, a higher revenue can be created. Many for-profit and comprehensive colleges and universities decided to provide tertiary-level education that is shorter in duration, more practical, less academically rigorous and less costly for students who may have another purpose (Constance \& Tierney, 2014).

\subsection{Donation and Income Sources}

Donation from other sources. The donation concept of non-profit colleges and universities is totally taken from for-profit colleges and universities. Following are the characteristics of non-profit colleges and universities and forprofit colleges and universities (Rush, 2001):

\subsubsection{Non-Profit Colleges and Universities}

First, non-profit colleges and universities seek normal donors, such as alumni, schools, community centres, families and business organisations (Turner, 2006). Second, non-profit colleges and universities like to spend time and energy on cultivating potential donors. Also, many of the college members, such as students, staff and teachers get involved in the donation activities. Third, non-profit colleges and universities invest their budgets in building new facilities, creating excellent scholars, introducing innovative researches to attract more students and seeking a higher national university ranking. Fourth, non-profit colleges and universities like to re-contribute their collected monies back to the local community for investment and educational purposes. Many public colleges and universities open their campus libraries to local residents and the public to give them the opportunity to read academic books and study in the university environment (Cellini., 2012). One of the goals is social responsibility. Another is to attract potential secondary school students to attend the university after high school graduation.

\subsubsection{For-Profit Colleges and Universities}

First, for-profit colleges and universities do not usually have local networks which are, relatively, as strong as non-profit institutions. It is hard for them to collect donations from nearby locations. Instead, for-profit institutions usually receive operational funding from stock markets. Many of the large for-profit institutions are members of the Wall Street stock market. Like many business organisations, for-profit institutions take opportunities to receive funding from the stock market to develop their curricula.

Second, unlike many of the non-profit institutions, fundraising activities do not usually involve many members of the college. In those institutions, funding affairs typically only involve senior management, supported by several professional staff members and investors. Students, academic teachers, staff and supporting personnel do not usually have the opportunity to join fundraising activities (Constance \& Tierney, 2014).

Third, for-profit colleges and universities do not have strong network connections with local businesses, community centres and related locations (Jacobson, LaLonde, \& Sullivan, 2005). This is unlike public community colleges and universities, where social responsibilities serve as a curriculum subject for students. Many public colleges and universities do not consider themselves as business organisations, rather as a specific type of community centre where young adults and working professionals can receive an education. The best interest of forprofit institutions is to make money for their investors. Therefore, social responsibility and local networking are not the priorities for their strategic plans.

Last but not least, fewer admission enrolments. One of the major concerns of the administrative sections of each college and university is enrolment management. Every college and university has to enrol enough students for each term in order to operate courses. However, currently, many traditional colleges and universities do not enrol enough students due to the increase of for-profit and online-based post-secondary institutions (Dolence, 1998).

\subsection{Enrolment Management}

Currently, many non-profit four-year universities require students to have several types of standardised examination scores, such as SAT I, SAT II, ACT, Advanced Placement (AP), CLEP and TOEFL, also an acceptable GPA score from high school and college, evidence of extra activities, volunteering experiences, foreign language proficiency and performance awards to be considered as applicants (Phelps, 2003; Syverson, 2007). On the other hand, many for-profit colleges and universities do not require any type of admission materials for admission acceptance (Breneman, 2006). Due to the less selective admission requirement, a relatively high enrolment rate is recorded in many for-profit colleges and universities.

Tuition discounting attract. For-profit colleges and universities are responsible for paying both state and federal taxes as business organisations. Almost ninety per cent of their revenue and operational funds are from tuition income (Rush, 2001). Each college and university has to enrol enough students to continue operating. The most common enrolment management concept is tuition discounting (Kraatz, Ventresca, \& Deng, 2010). The following points are suggestions for the strategic management relationship between tuition discounting and enrolment management increase:

a) Maintain desired enrolment levels.

b) Meet financial goals.

c) Manipulate the academic and demographic profiles of incoming classes.

Many current enrolment management practices are very similar to marketing price promotions. For example, many for-profit, post-secondary institutions allocate a large amount of their annual budget to online advertisements, public advertisements on buses, trains, televisions and searching machines. Research supports that advertisements promoting on public transport are especially aimed at the low and middle-income workforces for employment promotion (McPherson \& Schapiro, 1998). As mentioned above, many for-profit institutions offer practitioner-oriented degree programs because of employment promoting issues. The message about promoting and tuition discounting is very attractive to the low-income workforce. Moreover, the university financial aid 
department helps pre-enroled students to prepare and complete every essential financial document without the student having to do any laborious preparation. It can also increase student interest in the degree program which can ensure the enrolment rate (Kinser, 2006).

\subsection{Employment Management}

Reduce tenure-track instructors but hire adjunct faculty members. There are several useful suggestions on reducing the operational costs of for-profit colleges and universities. It is confirmed that hiring a tenure-track Associated Professor may cost more than $\$ 55,000$ USD per year, due to the coverage of benefit and compensation obligations. Below are some reasons why colleges and universities hire non-tenure-track instructors (Breneman., Pusser, \& Turner, 2006).

First, most non-tenure-track instructors teach first and second-year students. Courses are usually at the introductory level therefore do not require solid research. The trend in non-tenure-track faculty teaching is upwards (Lechuga, 2005).

Second, the authors also discovered that a large number of non-tenure-track instructors are in the humanities area. Unlike natural science and science-oriented subjects, the humanities do not require solid and innovative researches to support their teaching materials and direction. Although the increase of non-tenure-track instructors in the humanities is rapidly growing, the increase in the science area is significantly lower than humanities (Lechuga, 2005).

Third, contract appointment issues. Tenure-track instructors are usually leaders in the field and have announced several solid kinds of research in the area. Most of them are at least associated with full professor positions. Logically, older professors require a higher salary and better benefits package due to ageing, insurance, health and retirement coverage. However, such benefit packages require a much larger portion of the available budget to continue. However, if the college hires non-tenure-track instructors, no retirement and related packages are offered. The college reserves the rights to terminate the employment contract after the review period. Because of this, the college can handle faculty factors when facing financial difficulties (Moery, 2001).

\subsection{Customer-Oriented Service}

In many for-profit colleges and universities, schools usually focus on student experiences and the student satisfaction rate instead of the quality of education. Unlike any of the non-profit institutions, for-profit institutions do not concentrate mainly on campus construction or facilities management, not to mention sports activities or faculty tenure issues. One of the strongest interests must be money-making from its customers. To maintain student retention, customer service could be the best attraction. Also, for-profit colleges and universities tend to focus on the Return on Investment (ROI). If the activities do not benefit the revenue of the institutions, it is less likely the institutions will increase their facility management (Iloh, 2016).

Self-paced courses without normal instruction from professors (Cantoni, Cellario, \& Porta, 2004). There are several benefits of self-paced courses and distance learning courses for for-profit colleges and universities to consider. First, they are usually less expensive to deliver. Whether hiring a tenure-track or non-tenure-track instructor, the cost is high. Dual-mode universities are suffering many financial difficulties within the current economic environment. Many traditional-based classroom instructed courses are costly, which may work against the overall financial budget of the university. Since the 1970s and 1980s, the distance-learning based format has been introduced into the higher education field. As of today, many for-profit colleges and universities have exercised this learning format to reduce the cost of rental fees and other related operational fees (Rumble, 2012).

Second, students can access the courses when they need to. Using technology, learning becomes a common perspective in many colleges and universities in the United States. For the last two decades, many for-profit colleges and universities have adopted these technology-based learning concepts to operate distance-based and selfpaced learning courses to different academic levels. As is known, distance learning-based courses can save time and travel costs around commuting for both students and teachers. An additional advantage is for the many working professionals who do not have the time commitment to enter the classroom at an assigned time. In other words, the self-paced courses create the convenience for working professionals to access new knowledge in any location at any time (Russell, Kleiman, Carey, \& Douglas, 2009).

Third, students can skip the material they already know. Many distance learning students are working professionals. As technology grows rapidly in the educational field, many adults are allowed to use technological devices to access their assignments and discussion classrooms (Olesen-Tracey, 2010). Some of the largest student groups of distance-learning programs at for-profit colleges and universities are adults, females and low to middleincome personnel. For many middle-income working professionals, certain knowledge has been acquired by working experiences which may impact the way they were acquired (Chaves, 2006). The authors also mentioned that many working nurses have already acquired essential knowledge from working client experience. Many of the traditional classroom instruction courses may require several internships at the hospital which may not be necessary for experienced nurses. Also, some nursing students do not have enough time to allocate to hospital internships due to family commitments and other life events (Hicks \& Patterson, 2017).

Moreover, some traditional degree internship programs cannot be completed at the students' own organisation. In other words, the nursing students must find another hospital to complete the course requirement. Due to these inconveniences, many nursing students seek alternate ways to complete their degree programs in order to advance their career goals. The distance-based degree programs offered by different for-profit colleges and universities may satisfy the busy schedules of many experienced working professionals (Rothman \& Sisman, 2016). As suggested, many for-profit colleges and universities create practitioner-oriented programs to attract working professionals who seek career advancement. These schools usually create a professional-oriented curriculum, such as fewer research courses and fewer internship requirements to attract enough students. It is also a way to maintain enough students to continue their program development (Sides \& Mcvica, 2007). 
Fourth, providing consistent content. In a classroom environment, each teacher may have a different perspective on the subject, but distance-learning can avoid this potential bias of different materials. In many circumstances, distance-learning courses require only written discussions and several written projects and exams. Normal lecture instruction is absent from the courses. For a positive perspective, some students believe face-to-face instruction may not be fair because teachers may dislike certain student languages or expressions. But distancelearning courses do not contain any of the speech requirements; they can attract a group of students who may have a bias toward teachers. Also, for some distance-based for-profit colleges and universities, local centres may be available in several locations. For example, Argosy University operates at 19 different locations in the United States with a distance-learning curriculum program offered online. The purpose of the distance-learning curriculum is to provide real-world, skilled experience to working professionals. This can also satisfy some working professional students who want to experience face-to-face instruction at their local centre. Also, face-toface instruction at a local centre may allow students to build networking into their career path (Soliz, 2018).

Fifth, increasing retention and a strong grasp on the subject. Various materials can be combined into messages, videos, puzzles, games and discussions. For traditional classroom lectures, instruction time may constitute at least three-quarters of the class. However, in distance-learning based courses for adult students, the learning strategy may have been changed due to age differences or a conflict of experiences (Mikeska \& Alexander, 2018). Working professional adults usually enter college with responsibilities which are not common among traditionally-aged students. Also, unlike traditional students, working professionals do not have the time commitment to read several chapters of a textbook each week and complete a large amount of homework assignment for grading purpose. Fulltime employment, with family responsibilities, must be considered as the most important factors in their life at that time (Smith, 2008). To create interesting assignments for adult learners, many practitioner-oriented degree program sand for-profit institutions use videos, discussions and student-teacher interaction messages instead of traditional textbook materials.

Sixth, subject interest. Many public community colleges and non-profit higher education institutions tend to offer certificate and associate degrees in the subjects of humanities, arts, social sciences, liberal arts, general studies and communication (Breneman. et al., 2006). On the other hand, for-profit institutions usually offer vocational certificates, associated degrees, bachelor degrees, master degrees and even doctoral degrees in the areas of business, healthcare, health professionals, nursing, physical assistance, engineering technologies, computer sciences, psychology and criminal justice, which are practitioner-oriented programs for busy working professionals to attend to gain career advancement for promotion and/or career changes. Unlike arts and liberal arts training offered by many non-profit institutions, business and nursing programs provide students with the abilities to apply classroom knowledge to the workplace immediately after it is acquired. Due to the practitioner-oriented programs offered by many for-profit colleges and universities, the enrolment rate must be ensured for continuing growth (Turner, 2006).

\section{Conclusion}

The results and findings of financial planning and development suggests that many for-profit colleges and universities establish many interesting academic and vocational programs for working professional students to enroll in for career advancement and personal enhancement. As mentioned above, many working professionals hold several life responsibilities, such as full-time employment and family activities which may not allow them to attend traditional colleges to gain their post-secondary education in person. Because of this, many for-profit colleges and universities have established various types of practitioner-oriented degree programs for working professionals to enrol in. For-profit colleges and universities are not new concepts in American history.

The first for-profit institution was established at the time when Harvard University was founded. However, for-profit college and university numbers have been growing rapidly during the last two decades. One of the reasons why distance-learning based courses in for-profit colleges and universities are so attractive could be convenience. Several pieces of research support the fact that a large number of for-profit college and university students are adult students with low-income or middle-income class status (Strom \& Strom, 2011). Career advancement is one of the reasons for entering higher education. With a busy work schedule, a technologylearning format and coursework and materials which can be accessed online increase the chance for students to consider that particular distance-learning based institution.

Practitioner-oriented programs are very attractive for working professionals. Many public community colleges and universities traditionally offer liberal arts, general studies and humanities courses which working professional students may not be interested in. However, many for-profit colleges offer business management, nursing, technology and computer science programs as a result of which working professionals can apply their learned knowledge directly into the workplace immediately. This is especially significant for nursing degree programs, where nurses can gain promotions after receiving a bachelor's degree.

Unlike many public universities, the distance-learning based for-profit universities have redesigned the nursing program curriculum for working nurses to complete their internship requirements at their own hospital without any inconvenience. However, some limitations are found in the researched articles. One of the limitations of the researched articles is adult-oriented. Most of the articles did not discuss any of the traditionally-aged student enrolment management processes. For example, some traditionally-aged students may live in a rural community without any public community college within 100 miles from home. This group of students could be major customers of the for-profit colleges (Simonson, Smaldino, Albright, \& Zvacek, 2008). Also, the articles did not discuss the disadvantages of technology bias and how the distance-learning based college could instruct students who are unfamiliar with computer applications, such as Microsoft Office, and exercise online interactive assignments and discussions regularly $(\mathrm{Ng}, 2007)$.

In conclusion, each of the scholars contributes significant knowledge to the area of for-profit colleges and universities, adult education, financial management, enrolment management and program orientation. Though 
there is agreement amongst them and certain characteristics are coed-shared with each other with an understanding of, and appreciation for, learning knowledge and making progress on their path.

Two major directions are presented in the research, first, how for-profit colleges and universities can attract students to enrol in their programs instead of in public colleges. Second, in a rapidly changing environment, how these for-profit colleges can maintain their financial health to cover various operational expenses. Flexibility, practitioner-oriented programs and effective marketing advertisements are the three biggest elements to attract adult students to continue their education. However, traditionally-aged students and technological bias are omitted within this research. College administrators need to understand how to manage and handle their school's strategic management to overcome different impacts for communities and societies. No matter whether a public, private, non-profit or for-profit institution, not knowing financial strategies can be disastrous to every department within the college.

\section{References}

Banerjee, G. (2011). Blended environments: Learning effectiveness and student satisfaction at a small college in transition. Journal of Asynchronous Learning Networks, 15(1), 8-19. Available at: https://doi.org/10.24059/olj.v15i1.190.

Bowen, H. R. (1982). The state of the nation and the agenda for higher education. San Francisco, CA: Jossey-Bass.

Breneman, D. W. (2006). The University of Phoenix: Icon of for-profit higher education. In David W. Breneman, B. Pusser, \& S. E. Turner (Eds.), Earnings from Learning: The Rise of For-Profit Universitie (pp. 71-92). Albany, NY: State University of New York Press.

Breneman., D. W., Pusser, B., \& Turner, S. (2006). The contemporary provision of for-profit higher education: Mapping the competitive market. In D. Breneman, B. Pusser, \& S. Turner (Eds.), Earnings from Learning: The Rise of For-Profit Universities (pp. 3-23). Albany, NY: State University of New York Press.

Brint, S. (2006). Schools and societies (2nd ed.). Stanford, CA: Stanford University Press.

Brint, S., \& Karabel, J. (1989). The diverted dream: Community colleges and the promise of educational opportunities in America, 1900-1985. New York: Ocford University Press.

Cantoni, V., Cellario, M., \& Porta, M. (2004). Perspectives and challenges in e-learning: Towards natural interaction paradigms. Journal of Visual Languages \& Computing, 15(5), 333-345. Available at: https://doi.org/10.1016/j.jvlc.2003.10.002.

Cellini, S. R. (2010). Financial aid and for-profit colleges: Does aid encourage entry? Journal of Policy Analysis and Management, 29(3), 526552. Available at: https://doi.org/10.1002/pam.20508.

Cellini., S. R. (2012). For-profit higher education: An assessment of costs and benefits. National Tax Journal, 65(1), 153-179. Available at: https://doi.org/10.17310/ntj.2012.1.06.

Chaves, C. (2006). Involvement, development, and retention. Community College Review, 34(2), 139-152. Available at: https://doi.org/10.1177/0091552106293414.

Chung, A. S. (2012). Choice of for-profit college. Economics of Education Review, 31(6), 1084-1101. Available at: https://doi.org/10.1016/j.econedurev.2012.07.004.

Constance, I., \& Tierney, W. G. (2014). Understanding for-profit college and community college choice through rational choice. Teachers College Record, $116(8), 1-34$.

Deming, D. J., Goldin, C., \& Katz, L. F. (2012). The for-profit postsecondary school sector: Nimble critters or Agile predators? Journal of Economic Perspectives, American Economic Association, 26(1), 139-164. Available at: https://doi.org/10.3386/w 17710

Dolence, M. G. (1998). Strategic enrolment management. In Handbook for the college admission profession. Westport, CT: Greenwood.

Hicks, R., \& Patterson, R. (2017). Navigating nursing education. AORN Journal, 106(6), 523-533. Available at: https://doi.org/10.1016/j.aorn.2017.10.001.

Honick, C. A. (1995). The story behind proprietary schools in the United States. New Directions for Community Colleges, 1995(91), 27-40. Available at: https://doi.org/10.1002/cc.36819959105.

Iloh, C. (2016). Exploring the for-profit experience: An ethnography of a for-profit college. American Educational Research Journal, 53(3), 427455. Available at: https://doi.org/10.3102/0002831216637338.

Jacobson, L., LaLonde, R., \& Sullivan, D. (2005). Estimating the returns to community college schooling for displaced workers. Journal of Econometrics, 125(1-2), 271-304. Available at: https://doi.org/10.1016/j.jeconom.2004.04.010.

Johnstone, D. B., \& Marcucci, P. N. (2010). Financing higher education worldwide. Baltimore, MD: The Johns Hopkins University Press.

Killingsworth, R., McCurry, N., \& Hastie, P. (2006). The effect of class size on course and curriculum level performance for construction students. The International Journal of Learning: Annual Review, 13(2), 125-130. Available at: https://doi.org/10.18848/14479494/CGP/v13io2/44831.

Kinser, K. (2006). From main street to wall street: The transformation of for-profit education. ASHE Higher Education Report, 31 (5), 1-155.

Kraatz, M. S., Ventresca, M. J., \& Deng, L. (2010). Precarious values and mundane innovations: Enrollment management in American Liberal arts colleges. Academy of Management Journal, 53(6), 1521-1545. Available at: https://doi.org/10.5465/amj.20 10.57319260.

Lechuga, V. M. (2005). The changing landscape of the academic profession: Faculty culture at for-profit colleges and universities: Routledge.

McPherson, M. S., \& Schapiro, M. O. (1998). The student aid game: Meeting need and rewarding talent in American higher education. Princeton, NJ: Princeton University Press.

Mikeska, J., \& Alexander, J. (2018). Fitness professionals' perceptions and attitudes toward certification, online education, and medical fitness. International Journal of Kinesiology in Higher Education, 2(1), 1-14. Available at: https://doi.org/10.1080/24711616.2017.1328204.

Moery, A. (2001). The growth of for-profit higher education: Implications for teacher education. Journal of Teacher Education, 52(4), 300-311. Available at: https://doi.org/10.1177/0022487101052004004.

$\mathrm{Ng}$, C. (2007). Motivation among older adults in learning computing technologies: A grounded model. Educational Gerontology, 34(1), 1-14. Available at: https://doi.org/10.1080/03601270701763845.

Olesen-Tracey, K. (2010). Leading online learning initiatives in adult education. MPAEA Journal of Adult Education, 39(2), 36-39.

Phelps, R. (2003). Kill the messenger: The war on standardized testing (1st ed., pp. 331). New York: Routledge.

Rothman, M., \& Sisman, R. (2016). Internship impact on career consideration among business students. Education + Training, 58(9), 10031013. Available at: https://doi.org/10.1 108/ET-04-2015-0027.

Rubin, M. (2012). Social class differences in social integration among students in higher education: A meta-analysis and recommendations for future research. Journal of Diversity in Higher Education, 5(1), 22-38. Available at: https://doi.org/10.1037/a0026162.

Rumble, G. (2012). Financial management of distance learning in dual-mode institutions. Open Learning: The Journal of Open, Distance and eLearning, 27(1), 37-51. Available at: https://doi.org/10.1080/02680513.2012.640783.

Rush, R. S. (2001). Higher ed,inc: The rise of the for-profit university. Baltimore, MD: Johns Hopkins University Press.

Russell, M., Kleiman, G., Carey, R., \& Douglas, J. (2009). Comparing self-paced and cohort-based online courses for teachers. Journal of Research on Technology in Education, 41(4), 443-466. Available at: https://doi.org/10.1080/15391523.2009.10782538.

Sides, C., \& Mcvica, A. (2007). Internships: Theory and practice. New York: Taylor \& Francis.

Simonson, M., Smaldino, S., Albright, M., \& Zvacek, S. (2008). Teaching and learning at a distance: Foundations of distance education (4th ed.). New York: Pearson.

Smith, R. O. (2008). Adult learning and the emotional self in virtual online contexts. New Directions for Adult and Continuing Education, 120(1), 35-43. Available at: https://doi.org/10.1002/ace.314.

Soliz, A. (2018). The effects of the expansion of for-profit colleges on student enrolments and outcomes at community colleges. Educational Evaluation and Policy Analysis, 4O(4), 631-652. Available at: https://doi.org/10.3102/0162373718795053. 
Strom, P., \& Strom, R. D. (2011). Adult learning and relationships. Charlotte, NC: Information Age Publication.

Syverson, S. (2007). The role of standardized tests in college admissions: Test-Optional admissions. New Directions for Student Services, 118 , 55-70. Available at: https://doi.org/10.1002/ss.241.

Turner, S. E. (2006). For-profit colleges in the context of the market for higher education. In D. Breneman, B. Pusser, \& S. Turner (Eds.), Earnings from Learning: The Rise of For-Profit Universities (pp. 51-70). Albany, NY: State University of New York Press. 